\title{
Electric Vehicle. A cyclical story of death and resurrection.
}

\author{
Portela Núñez J. M ${ }^{\mathrm{a}}{ }^{1}$, Pastor Fernandez A. ${ }^{1}$, Huerta Gomez de Merodio M. M. ${ }^{1}$, Otero Mateo, Manuel ${ }^{1}$, Viguera \\ Cebrian ${ }^{1}$, J. L. and Diaz Vázquez, J.E. ${ }^{1}$ \\ ${ }^{1}$ Department of Mechanical Engineering and Industrial Design \\ E.S.I., Cádiz University \\ c/Chile n ${ }^{\circ} 1,11002$ Cádiz (Spain)
}

Phone/Fax number:+0034956015142, e-mail: josemaria.portela@uca.es, andres.pastor@uca.es, milagros.huerta@uca.es, manuel.otero@uca.es, jlviguera@uca.es, enrique.diaz@uca.es

\begin{abstract}
An electric car is powered by an electric motor instead of a gasoline engine. The electric motor gets energy from a controller, which regulates the amount of power. The electric car (EV) uses energy stored in its rechargeable batteries, which are recharged by common household electricity.
\end{abstract}

Historically, EVs have not been widely adopted because of limited driving range before needing to be recharged, long recharging times, and a lack of commitment by automakers to produce and market electric cars that have all the creature comforts of gas-powered cars. That's changing. As battery technology improves (increasing energy storage and reducing cost).

Electric cars no produce $\mathrm{CO}_{2}$ emissions, reduce our dependency on oil, and are cheaper to operate. Of course, the process of producing the electricity produce emissions, but even dirty electricity used in electric cars usually reduces our collective carbon footprint.

It showed briefly the evolution of electric vehicles associated with the technological advances and costs.

\section{Key words}

Electric vehicle, Electric cars, Battery electric vehicle.

\section{Introduction}

Electric cars enjoyed popularity between the mid-19th century and early 20th century, when electricity was the preferred methods for automobile propulsion, providing a level of comfort and ease of operation that could not be achieved by the gasoline cars of those years.

Advances in internal combustion engine technology soon rendered this advantage moot; the greater range of gasoline cars, quicker refueling times, the invention of the electric starter which eliminated the need of a hand crank for starting a gasoline engine, reduction of the noise emitted by internal combustion engine thanks to the use of the muffler, growing petroleum infrastructure, along with the mass production of gasoline vehicles by companies such Ford, which reduced prices of gasoline cars to less than half that of equivalent electric cars, led to a decline in the use of electric propulsion, effectively removing it from important markets such as the United States by the 1930s.

In recent years, increased concerns over the environmental impact of gasoline cars, along with reduced consumer ability to pay for fuel for gasoline cars, has brought about renewed interest in electric cars, which are perceived to be more environmentally friendly and cheaper to maintain and run, despite high initial costs.

In 1897, electric vehicles found their first commercial application as a fleet of electrical New York City taxis.

In 1917, the first gasoline-electric hybrid car was released by the Woods Motor Vehicle Company of Chicago. The hybrid was a commercial failure, proving to be too slow for its price, and too difficult to service.

By the 1920s, the heyday of electric cars had passed, and a decade later, the American electric automobile industry had effectively disappeared [1].

The first modern electric car based on transistor technology, the Henney Kilowatt (Fig. 1), was built in 1950s, this car improved performance with respect to previous electric cars, consumers found it too expensive compared to equivalent gasoline cars of the time, and production ended in 1961.

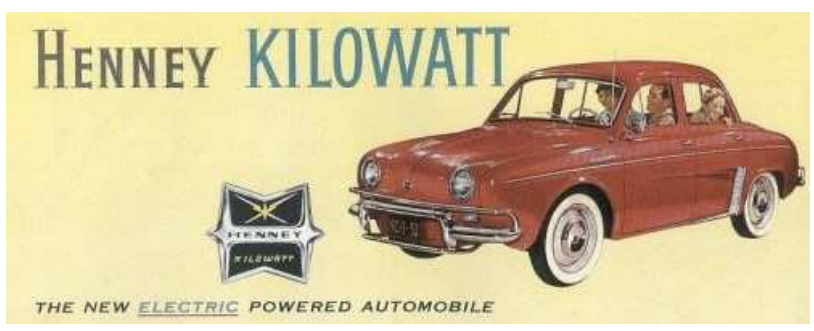

Fig. 1. Henney KILOWATT

The energy crises of the 1970s and 80s brought about renewed interest in the perceived independence electric 
cars had from the fluctuations of the hydrocarbon energy market. At the 1990 Los Angeles Auto Show, General Motors President Roger Smith unveiled the GM Impact concept electric car, along with the announcement that GM would build electric cars for sale to the public, the EV1 model, but was retired in 1996 of the market.

Today it is possible to find many models of electric vehicles such as those offered by the catalogue of Movel project in Spain.

Specifications of last models of electric vehicles are shown in Table I. and in Table II. a comparison between a new and old EV.

Table I. - Specifications EV

\begin{tabular}{|c|c|c|c|c|}
\hline Model & $\begin{array}{c}\text { Accele. } \\
0-100 \\
\mathbf{k m} / \mathbf{h} \\
\mathrm{s}\end{array}$ & $\begin{array}{c}\text { Range } \\
\text { km }\end{array}$ & $\begin{array}{c}\text { Top } \\
\text { speed } \\
\mathbf{k m} / \mathbf{h}\end{array}$ & $\begin{array}{l}\text { Consump. } \\
\text { kWh/km }\end{array}$ \\
\hline$\underline{\text { BMW }}$ & 8.5 & 240 & 152 & 0.12 \\
\hline Ford e-Ka & 12.7 & 150 & 130 & 0.19 \\
\hline$\frac{\text { Mitsubishi }}{\mathrm{i} \mathrm{MiEV}}$ & 11.6 & 144 & 130 & 0.16 \\
\hline$\frac{\text { Tesla }}{\text { Roadster }}$ & 3.9 & 400 & 200 & 0.13 \\
\hline Model & $\begin{array}{c}\text { Weight } \\
\text { kg }\end{array}$ & $\begin{array}{c}\text { Battery } \\
\text { V \& } \\
\text { kg }\end{array}$ & $\begin{array}{l}\text { Output } \\
\text { kW }\end{array}$ & $\begin{array}{c}\text { Battery } \\
\text { capacity } \\
\text { kWh }\end{array}$ \\
\hline$\underline{\text { BMW }}$ & 1465 & $\begin{array}{c}380 \& \\
260\end{array}$ & 150 & 35 \\
\hline$\underline{\text { Ford e-Ka }}$ & 1134 & $\begin{array}{c}\& \\
280\end{array}$ & 65 & 51 \\
\hline$\frac{\text { Mitsubish }}{\mathrm{i} \text { i MiEV }}$ & 1080 & $\begin{array}{c}330 \& \\
165\end{array}$ & 47 & 16 \\
\hline $\begin{array}{c}\text { Tesla } \\
\text { Roadster }\end{array}$ & 1130 & $\begin{array}{c}48 \& \\
450\end{array}$ & 185 & 56 \\
\hline
\end{tabular}

Table II. - Comparison between an old and a new EV

\begin{tabular}{|c|c|c|c|c|}
\hline Model & $\begin{array}{c}\text { Weight } \\
\mathbf{k g}\end{array}$ & $\begin{array}{c}\text { Top speed } \\
\mathbf{k m} / \mathbf{h}\end{array}$ & $\begin{array}{c}\text { Range } \\
\mathbf{k m}\end{array}$ & $\begin{array}{c}\text { Power } \\
\mathbf{h p}\end{array}$ \\
\hline $\begin{array}{c}\text { Baker } \\
\text { Electric }\end{array}$ & 445 & 22.4 & 66 & 1,75 \\
$\begin{array}{c}\text { Stanhope } \\
(1904)\end{array}$ & & & & \\
\hline $\begin{array}{c}\text { Tesla } \\
\text { Roadster } \\
(2009)\end{array}$ & 1130 & 200 & 400 & 248 \\
\hline
\end{tabular}

\section{Comparison with internal combustion engine.}

Electric car operating costs can be directly compared to the equivalent operating costs of a gasoline-powered vehicle. The energy generated by complete combustion of 1 liter gasoline is about 9.7 kilowatt-hours (35 MJ). Accounting for inefficiencies of gasoline vs. electric engines and transmission and battery losses, 1 liter gasoline is equivalent to 2.7 kilowatt-hours $(9.7 \mathrm{MJ})$ from batteries [2].An electric car's efficiency is affected by its charging and discharging efficiencies, which ranges from $70 \%$ to $85 \%$.

In EEUU, for comparison, driving an internal combustion engine-powered (ICE) car is approximately 4 times more expensive than charging the electric car. In UE fuel is more expensive. This cost advantage varies depending on the costs of gasoline and electricity, the $\mathrm{kms}$ of the vehicles, and the type of driving being considered.

The cost advantage of electric cars increases in start-andstop city driving because the regenerative braking systems of the newer electric cars recapture much of the kinetic energy of the moving vehicle and use this to recharge the batteries upon braking. Impossible for gasoline powered vehicles, which lost this energy as heat.

But, during highway driving, most of the energy used to move the car forward is dispersed through wind resistance, which is not easily recoverable. In this case, gasoline powered cars compare more favourably with electric cars.

Typically a cruising speed of around $80 \mathrm{~km} / \mathrm{h}$ is nearoptimal for vehicle with internal combustion engines. For electric vehicles the equation is less complex, and maximum range is achieved at comparatively low speeds.

An EV delivers full availability of performance every moment you are in the car, even while at a stoplight. Its peak torque begins at $0 \mathrm{rpm}$. More or less $100 \%$ torque all the time.

This is the precise opposite of the experience with a gasoline engine, which has very little torque at a low rpm and only reaches peak torque in a narrow rpm range. This forces to make frequents gear changes to maintain optimal torque. With EV it is possible to get great acceleration and the highest energy efficiency at the same time.

The Standard Torque Curve of EV and ICE are shown in Fig. 2.

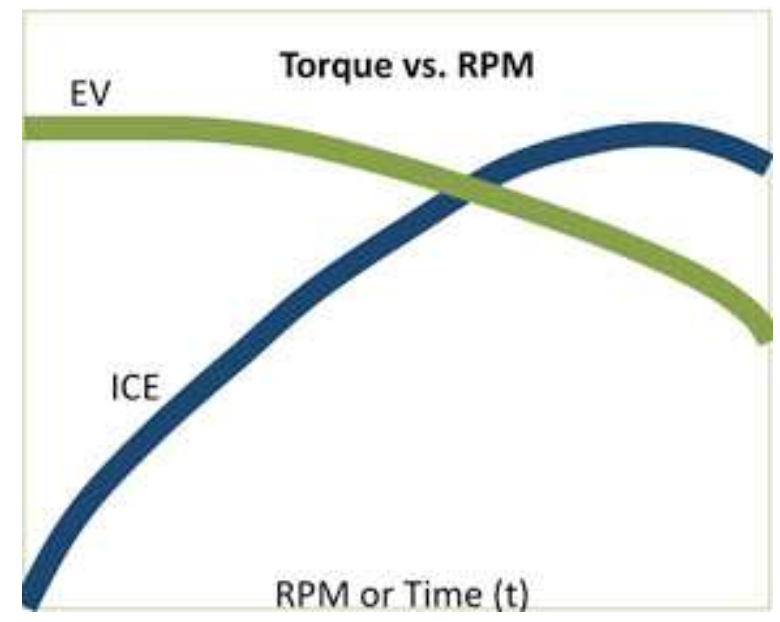

Fig. 2. Standard Curve, Torque vs. RPM in a EV \& ICE 
Although some electric vehicles have very small motors, $15 \mathrm{~kW}(20 \mathrm{hp})$ or less and therefore have modest acceleration, the relatively constant torque of an electric motor even at very low speeds tends to increase the acceleration performance of an electric vehicle for the same rated motor power.

Electric cars increases demand for power plants. Generating electricity and producing liquid fuels for vehicles are different categories of the energy economy, with different inefficiencies and environmental harms, but both emit carbon dioxide into the environment.

In EEUU an EV emits about 115 grams of $\mathrm{CO} 2$ per kilometer driven, and a conventional ICE powered car emits $250 \mathrm{~g}(\mathrm{CO} 2) / \mathrm{km}$ [3], in UE the most efficient cars are below 115 grams of $\mathrm{CO} 2$ per kilometre driven and the average is of $170 \mathrm{~g}(\mathrm{CO} 2) / \mathrm{km}$ for a gasoline powered compact car.

The energy efficiency comparison of an electric vehicle to one powered by an internal combustion engine, is difficult to make because the two vehicles operate on different principles.

Combustion engines operate by converting energy stored in fossil fuels to mechanical energy through the use of a heat engine. The main problem is a very low efficiency because heat cannot be converted directly into mechanical energy.

Electric vehicles convert stored electric potential into mechanical energy. Electricity can be converted into mechanical energy at very high efficiencies.

A quick analysis will show electric vehicles are significantly more efficient. However, electricity used in EVs not naturally exists in nature. The electricity used for EVs may be created by converting fossil fuels to electricity, converting nuclear energy to electricity, or a more environmental electricity from windmills, or solar energy.

Production and conversion electric cars typically use 10 to $23 \mathrm{~kW} \cdot \mathrm{h} / 100 \mathrm{~km}$. Approximately $20 \%$ of this power consumption is due to inefficiencies in charging the batteries [4].

The greater efficiency of electric vehicles is because most energy in an internal combustion engine-powered vehicle is released as waste heat ( $20 \%$ thermal efficiency), an internal combustion engine-powered vehicle using 96 $\mathrm{kW} \cdot \mathrm{h} / 100 \mathrm{~km}$ of energy is only using $19.2 \mathrm{~kW} \cdot \mathrm{h} / 100 \mathrm{~km}$ for motion.

The waste heat generated by an ICE is used by heating the vehicle interior. Electric vehicles used in cold weather will show increased energy consumption and decreased range on a single charge.

For the cabin of the electrical vehicles the higher efficiency in heating and cooling can be obtained with a reversible heat pump (Toyota Prius), but for example the
Citroën Berlingo Electrique, use an auxiliary heating system (for example gasoline-fueled).

Electric cars are being heavier than a similar equivalent gasoline vehicle, this is bad for the range and endurance of the vehicle. But, in a collision, the occupants of a heavy vehicle will, on average, suffer fewer and less serious injuries than the occupants of a lighter vehicle; therefore, the additional weight brings safety benefits[5].

\section{Batteries}

Historically, electrical vehicles have had issues with high battery costs, limited range between battery recharging, charging time, and battery lifespan, which have limited their widespread adoption. Ongoing battery technology advancements have addressed many of these problems.

Electric cars using lead-acid batteries require their regular replacement. NiMH batteries typically last the life of the vehicle. Toyota Prius vehicles have been known to go over $300,000 \mathrm{~km}$ without needing a battery replacement, though the Toyota warranty is for 10 years $/ 240,000 \mathrm{~km}$ or 8 years $/ 160,000 \mathrm{~km}$.

The future of battery electric vehicles depends primarily upon the cost and availability of batteries with high energy densities, power density, short charge time and long life, as all other aspects such as motors, motor controllers, and chargers are fairly mature and costcompetitive with internal combustion engine components.

Prototypes of 75 watt-hour/kilogram lithium-ion polymer battery. And newer lithium-ion cells can provide up to $130 \mathrm{~W} \cdot \mathrm{h} / \mathrm{kg}$ and last through thousands of charging cycles.

Li-ion, Li-poly and zinc-air batteries have demonstrated energy densities high enough to deliver range and recharge times comparable to conventional vehicles, but the price is too high.

Charging time is limited primarily by the capacity of the grid connection. A normal household outlet is $3 \mathrm{~kW}$ (in countries with $220 / 240 \mathrm{~V}$ supply). The main connection to a house might be able to sustain $10 \mathrm{~kW}$, and special wiring can be installed to use this. At this higher power level charging even a small, $7 \mathrm{~kW} \cdot \mathrm{h}(22-45 \mathrm{~km})$ pack, would probably require one hour.

In EEUU, the charging power can be connected to the car using a direct electrical connection, as simple as a mains lead into a weatherproof socket through special high capacity cables with connectors to protect the user from the high voltage ; several standards, such as SAE J1772 and IEC 62196, cohabit. The second system is known as inductive charging. A special 'paddle' is inserted into a slot on the car. The paddle is one winding of a transformer, while the other is built into the car. When the paddle is inserted it completes an electromagnetic circuit which provides power to the battery pack. This inductive charging system avoids electric shock. 
Lead acid batteries are still the most used for most of the electric vehicles used today. Because costs are significantly lower than for other battery types, and while power output to weight is poorer than other designs, range and power can be easily added by increasing the number of batteries. Production EVs with lead-acid batteries are capable of up to $130 \mathrm{~km}$ per charge.

NiMH batteries have higher energy density and may deliver up to $200 \mathrm{~km}$.

The lithium-ion battery may deliver $400 \mathrm{~km}$, is also less expensive than nickel.

A new energy storage devices offer comparable storage capacity, faster charging, and lower volatility, (an experimental supercapacitor). They have the potential to overtake batteries as the preferred rechargeable storage for EVs.

The factors that influence driving range in an EV are best explained by this simple formula:

Range $(\mathrm{km})=$ battery useable energy $(\mathrm{kWh}) \mathrm{x}$ vehicle energy efficiency $(\mathrm{km}$ per $\mathrm{kWh})$

So if EV has useable battery energy of $25 \mathrm{kWh}$ and efficiency of $4 \mathrm{~km}$ per $\mathrm{kWh}$, the range will be $100 \mathrm{~km}$.

The formula tells us that, to get a high range, the EV must be equipping with a lot of useable battery energy and design the EV to use this energy efficiently.

However, as the above range formula shows, a highenergy battery on its own does not guarantee a high range also it is necessary to use the energy wisely.

Excess weight is detrimental to performance and handling, but it's also the enemy of efficiency.

Energy losses due to acceleration/braking, hill climbing and tire friction are directly proportional to weight and together these account for a major fraction of a vehicle's energy use.

Most plug-in electric cars require about 8 hours for a full charge, which means that battery is basically starting from zero. The average charge time is more likely to be somewhere between 2 and 6 hours.

For the future Renault ZE will be available 3 types of charging system.

The first one is the standard charging. Type of connection is a standard domestic socket $220 \mathrm{~V}-10 \mathrm{~A}$ or $16 \mathrm{~A}$ and the charging time is 6 to 8 hours for a complete vehicle recharge. For security, there is an automatic key system. Some manufactures, including Renault are working with RWE on the standardisation of a high power multipurpose electrical socket (future standard in EU). This socket was presented in Hannover on April 2009.
The second one is fast charging. Socket type: High power socket $(400 \mathrm{~V}-36 \mathrm{~A})$. Charging time: 20 to 30 minutes to recharge a $20 \mathrm{kWh}$ battery (infrastructure is in the process of development), and use the same high power multipurpose electrical socket.

And the third one is quickdrop charging (battery exchange, 3 minutes for a new fully-charged battery), as shown in Fig. 3. When: On open roads or motorways to "top up" the battery operating life during a long journey, or for standard charging when there is not enough time.

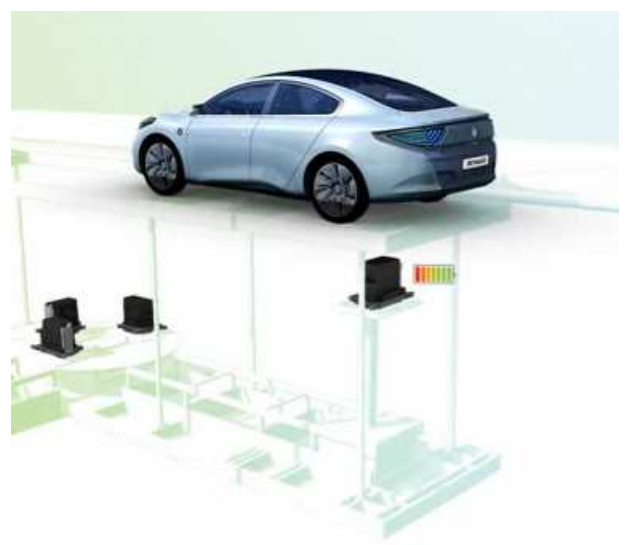

Fig. 3. Quickdrop charging system

Fig. 4. shows a comparison of the range in kilometres of EVs from the last 15 years depending on the speed parameter and drive cycle range with a full charge of the battery [6].

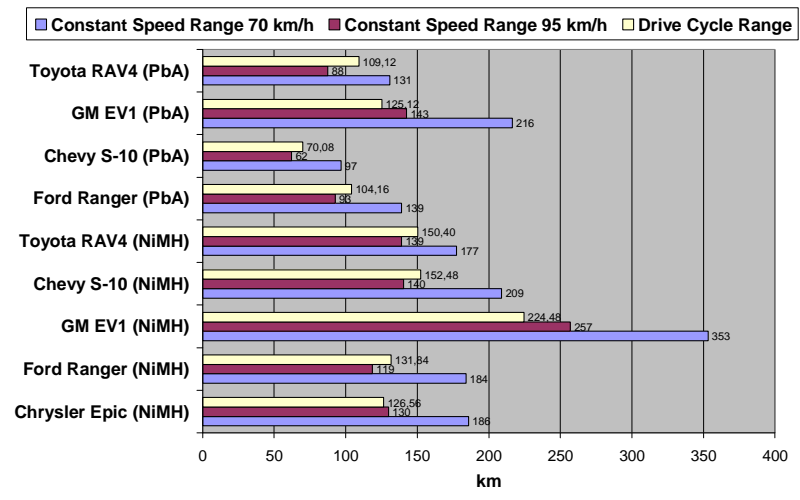

Fig. 4. Comparison between different EVs

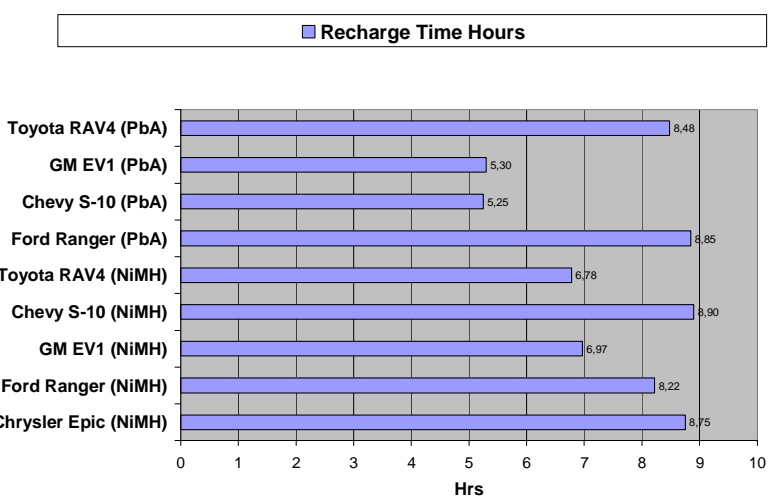

Fig. 5. Recharge time in hours between different EVs 
Fig. 5. shows a comparison of full recharge time in hours between different EVs from the last 15 years.

\section{Conclusion}

$\mathrm{CO}_{2}$ emissions of electric cars are lower than those of conventional cars, but the amount of savings depend on the emissions intensity of the existing electricity infrastructure. Now it is possible to find charging stations that avoid this problem. For example, solar stations like the show in Fig. 6, Bolzano (Italy).

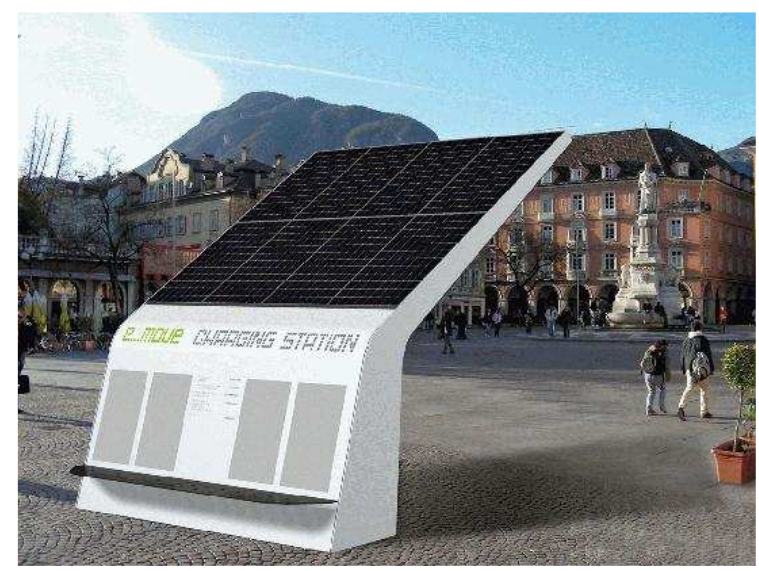

Fig. 6. Charging station (solar energy)

A potential hazard is the reduced noise level from electric engines that may not be beneficial for all road users, as blind people. Tests have shown that vehicles operating in electric mode can be particularly hard to hear below 30 $\mathrm{km} / \mathrm{h}$. At higher speeds the sound created by tire friction and the air displaced by the vehicle start to make more audible noise.

A new type of electric vehicles is now under study for zero $\mathrm{CO}_{2}$ emissions. Solar cars are electric cars that derive most or all of their electricity from built in solar panels.

New infrastructure in Spain to promote the use of EVs are being carried out, on 8 September 2009 the Spanish Industry Minister Miguel Sebastián announced that in late 2010 electric cars will be relisted in Spain. Madrid, Barcelona and Seville will provide charging points[7].

For less of sixty kilometres each day EVs and neighbourhood electric vehicles (NEVs) in particular, are perfectly suited to this type of driving.

EVs have low to no maintenance requirements.

EVs have better torque curve. For example, Tesla Motor's Roadster can go from 0 to 100 in 3.9 seconds, which is as fast many of the fastest gas-fueled cars on the road. Other more traditional electric cars are not as fast, they are like similar class vehicles.

\section{References}

[1] Electric automobile. Encyclopaedia Britannica Online. N.p., n.d. Web. Oct. 2009

[2] 10 CFR Part 474 Electric and Hybrid Vehicle Research, Development, and Demonstration Program; PetroleumEquivalent Fuel Economy Calculation; Final Rule, United States Department of Energy, Federal Register 64 pp.113.

[3] "Wheel to Well Analysis of EVs" (PDF). MIT Electric Vehicle Team. MIT. April 2008. http://web.mit.edu/evt/summary wtw.pdf. Web. Dec. 2009.

[4] "Advanced Vehicle Testing Activity", Full Size Electric Vehicles, Idaho National Laboratory, 30 May 2006, http://avt.inel.gov/fsev.html, Web. Dec. 2009

[5] Effectiveness and impact of corporate average fuel economy (CAFE) standards. Books.google.com.au. National Research Council (U.S.). Committee on the Effectiveness and Impact of Corporation. pp. 71-72

[6] Tables comparison between vehicles. http://www1.eere.energy.gov/vehiclesandfuels/avta/light_d uty/fsev/fsev_eva_results.html. Web. Dec. 2009.

[7] El coche eléctrico, una "cuestión de Estado", El País, 8 September 2009,

http://www.elpais.com/articulo/sociedad/coche/electrico/cu estion/Estado/elpepisoc/20090908elpepusoc 7/Tes, Web. Dec. 2009. 